\title{
Raising the relevance to outside needs
}

Museums may be increasingly asserting the unique value of their traditional collectionsbased research. But their directors appear keenly aware that museum research can no longer remain an end in itself, and must be increasingly geared to answering questions of contemporary relevance - in particular about the management of the environment and biodiversity.

Two manifestations of this are a new emphasis on multidisciplinary research, and greater willingness to collaborate with external researchers. "The future of all natural history museums will depend on the strategic alliances we are able to build with other organizations to increase our reach and broaden our impact," says Peter Crane, director of the Field Museum in Chicago. "We will need to develop an institutional culture that looks outwards rather than inwards."

The Field Museum is bringing together scientists from different departments around shared facilities, for example in molecular biology. Similar proposals are contained in reforms submitted to the French government by Henry de Lumley, director of the Muséum National d'Histoire Naturelle in Paris. The museum's 26 laboratories would be regrouped in 'institutes' built around particular research themes and collections - such as ecology and the management of biodiversity - with each sharing equipment and facilities.
At the Natural History Museum in London, reforms to encourage staff to seek research collaboration, both within the museum and in the wider community, have been under way for a decade (see opposite). Competition for external grants, for example, has become an important factor in internal promotion.

The museum's research was previously too "cut off" from the outside world, argues Neil Chalmers, the museum's director. He says he felt when he took over in 1989 that there was a need to have the museum's unique research product - taxonomy better appreciated outside the museum.

Paul Henderson, the museum's director of science, sees the forging of external alliances as crucial to the institution's future. He would like to see a graduate school developed between the museum and the University of London, for example, in much the same way as the American Museum of National History in New York has long had a productive link with Columbia University.

More broadly, managers at the London museum increasingly see its collection of 68 million specimens as a sort of collateral for attracting funds and staff for studies in such areas as biodiversity, conservation, agriculture, waste management, water treatment, and mineral exploitation.

Promoting the value of its collections for addressing contemporary problems, such as in biodiversity and the environment, has become the focus of the museum's development strategy. Chalmers defends himself against accusations that this amounts to chasing fashion at the expense of long-term interests by arguing that it reinforces the relevance of the collections in the eyes of funders.

A similar pragmatism now permeates many regional natural history museums, particularly in the United States. The Field Museum, for example, has become heavily involved in local issues, bringing together more than 40 state and local agencies and associations to form a conservation network known as the Chicago Wilderness Initiative.

"The funding opportunities are local," says Edward Theriot, director of the Texas Memorial Museum in Austin, arguing that the central question facing all museums is one of "relevance". Although scientific meetings may be preoccupied with global biodiversity, the museum is having to focus its biodiversity efforts on problems relevant to Texas, he says.

Similarly, Michael Hager, director of the San Diego Museum of Natural History, says the museum has completely refocused its activities over the past decade from global issues to biodiversity and environmental issues in California and Mexico. "The world kind of opened up for us, with funding becoming readily available," says Hager, adding that ten years ago the museum was close to closing its doors.

\section{Museum world gears up to the 'big bang' of informatics}

"What would Linnaeus have invented if he had lived in the twenty-first century and grown up with the Internet?" The question is posed in the prologue to a plan to create and link biodiversity databases around the world to provide a computer-based infrastructure similar to that which exists for molecular biology and genome research.

The proposal for a Global Biodiversity Information Facility (GBIF) has been put forward by the Working Group on Biological Informatics of the Megascience Forum of the Organization for Economic Cooperation and Development (OECD).

It is by far the largest of several initiatives to make collections-based research and information available to a wider audience by digitizing it and putting it on networked databases. It can then be integrated with information and maps on the ecology and biogeography of species, to provide sophisticated tools for the management of biodiversity and ecosystems.

The basic goal of the proposal is to create a web homepage for every species on the planet, beginning with existing data, and

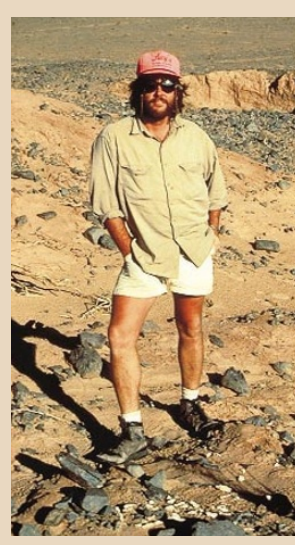

Novacek: faster progress needed on collaboration. (a) programme is likely to be submitted for initial funding to OECD ministers next year. If approved, it would probably be brought under the umbrella of the United Nations Biodiversity Convention. "An immense amount of support is growing for GBIF," says Steve Blackmore, keeper of botany at London's Natural History Museum.
Many museum directors agree that digitization of the world's collections, and their inclusion on web-based databases, is the way forward. Neil Chalmers, director of London's Natural History Museum, argues that exploiting the opportunities offered by networked databases is essential to "translating research-based information in a form that is accessible and useful".

"The major challenge now is to mobilize information on collections with geographical information system databases, to map flora and fauna in underexplored areas or for underexplored groups," says Pieter Baas, chairman of Diversitas's working group on creating a species inventory of the planet (see page 116).

An international initiative is imperative because the costs of digitalization are beyond the budgets of individual institutions. "Digitalizing the collections is essential," says Ghillean Prance, director of the Royal Botanic Gardens, Kew, in London. "But none of the big museums can afford to do it in a serious way - we are only doing little bits."

At first, GBIF is expected to be selective to 


\section{Chalmers' choice: make cuts or go under}

Few museums have witnessed as profound a transformation in recent years as the Natural History Museum in London has under the directorship of Neil Chalmers. museum was struggling to make ends meet and almost totally dependent on dwindling public funds, all but two per cent of which were eaten up by salaries. But in the last

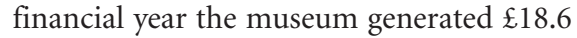
million (US\$31 million) of its $\mathfrak{£} 46.3$ million turnover itself-just over 40 per cent.

Chalmers' actions have been controversial. They involved shedding or redeploying about 50 of the 290 scientific, curatorial and technical support posts, and refocusing research on fewer areas, putting some collections on a 'care-and-maintenance' footing (see Nature 344, 805; 1990).

Many experts in fields considered to be outside the museum's core interests have taken early retirement. Ten years on, there are now 270 staff funded by the museum, with a further 55 postdoctoral fellows and other staff paid by external agencies.

The link between museum research and the health of taxonomy and systematics as a discipline is a strong one. When the museum announced the job cuts in 1990, the then president of the Royal Society, Sir George Porter, received more than 800 letters, "all expressing concern that the great collections of the Natural History Museum and the research associated with them were in danger of neglect or
When he took up the post in 1988, the

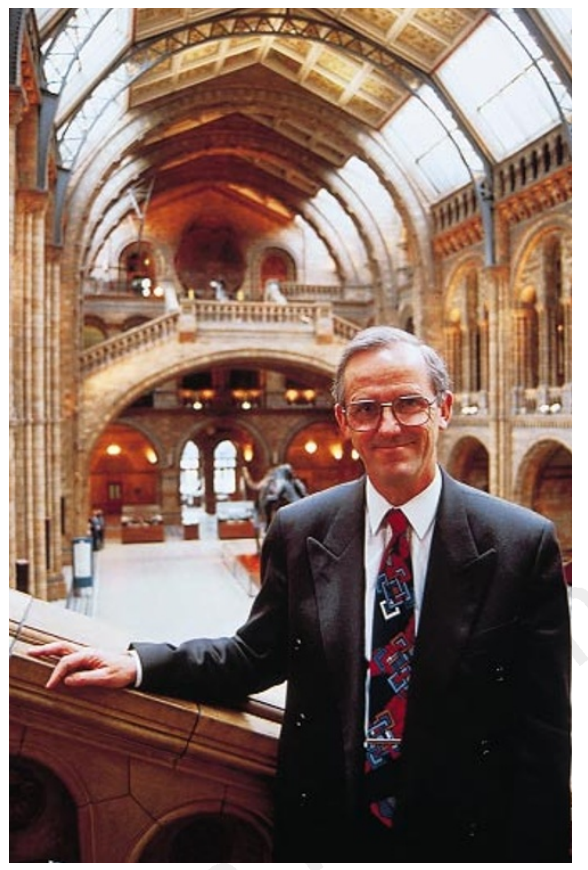

Chalmers: the results of museum research must be made public more speedily and effectively.

extinction through lack of support".

As a result, the House of Lords Committee on Science and Technology set up an inquiry into the state of systematic biology in the United Kingdom. Their recommendations, published in January 1992, included a modest increase in funding $-\mathfrak{E} 5$ million

keep costs down, focusing only on the most endangered or ecologically important groups. Given the sheer size of the world's collections, "you are talking millions, even if you only spend a few dollars per beetle," points out Stephan Michalowski, executive secretary of the OECD Megascience Forum.

Co-ordinating existing digitalization programmes is also a goal of the

Consortium of European Taxonomic Facilities, a grouping of the major European museums. Similarly, an informal consortium of a dozen leading US museums is discussing co-ordinating their systematics work, including digitalization.

"We've made some progress, but it hasn't been enough," says Michael Novacek, provost of the American Museum of Natural History in New York. "Museums have had difficulty joining together to work on things because a lot of them have had to contend with challenges at home," he adds.

Discussions are also under way to integrate a UK-led programme, Species 2000 , as the core of the early phases of GBIF. Species 2000 was launched in 1994 by the
International Union of Biological Sciences, in co-operation with the Committee on Data for Science and Technology and the International Union of Microbiological Societies.

The initiative has set its sights lower than GBIF, and would focus on bringing together databases of only existing described species to form a shared resource, while stopping short of digitalizing the specimens. Work is already under way to enter 40 per cent of the world's described species. Much of the information is coming from major museums, particularly in Europe.

Frank Bisby, professor of botany at the University of Reading in the United Kingdom and the chairman of the project, says that "pragmatism and quality" are its key criteria.

"Why haven't the taxonomists done this before?" asks Bisby. "At the moment there is gross inefficiency, with information distributed throughout countries and "desktop delivery of the world's existing knowledge on biodiversity". institutions." What we are planning is over five years - for systematics and taxonomy (see Nature 355, 488; 1992).

By a fortuitous coincidence, the debate on the committee's report in the House of Lords came soon after the United Nations Earth Summit in Rio de Janeiro. At the summit meeting, the then Prime Minister, John Major, announced the Darwin Initiative, to provide modest sums $-\mathfrak{E} 6$ million to date - for systematics. Under the initiative, staff from museums and botanic gardens train taxonomists from developing countries.

Much of the resistance of researchers to the changes at the museum stemmed from opposition to the disbanding of teams of collections-based researchers on certain groups of species. The cuts have undoubtedly resulted in the irretrievable loss of a wealth of expertise which will have repercussions on the museum's activities for decades.

The cuts have been compensated for to some extent by the recruitment of around 100 university-style postdoctoral researchers financed by external agencies, such as the Natural Environment Research Council.

Two positive outcomes of the influx of outside scientists have been heightened external awareness of the museum's activities, and a greater 'footprint' in peerreviewed journals, according to the director of science, Paul Henderson.

A further boost to researcher mobility has come from the recent award of a ECU680,000 (US\$750,000) grant from the European Union's Framework research programme to fund researchers from other European countries to visit the museum for up to three months at a time.

But financial austerity has forced the museum to abandon its scheme for funding undergraduates to spend the summer doing curatorial work, closing an avenue that in the past opened up careers for many scientists.

Chalmers defends his tough actions on the grounds that the urgency of the situation made drastic action necessary and that otherwise "we would have gone into a long and painful decline". Exhibitions would have been lacklustre, he argues, staff would have left and not been replaced, while the science would have become fragmented and unsupported, with no focus or plan.

According to Chalmers, a crucial challenge to museums in meeting real world needs will be to make collections-based research and information available in a form and at a speed — "unfamiliar to many who work in museums" - that makes them accessible to a wide range of users.

Chalmers argues that this requires researchers to communicate data "in brief and rapid reports," rather than in scholarly monographs, while taking full advantage of networked databases. 